\title{
Intraventricular conduction defects
}

\author{
Milad Rashidbeygi, ${ }^{1}$ Maryam Soleimannejad ${ }^{2}$ \\ ${ }^{1}$ Student Researcher Committee, llam University of Medical Sciences, Ilam, Iran \\ ${ }^{2}$ llam University of Medical Sciences, llam, Iran
}

Correspondence to Dr Milad Rashidbeygi, miladrashidbeygi@yahoo.com

\section{DESCRIPTION}

A 62-year-old woman with ischaemic heart disease reported having dyspnoea, chest pain in the left hemithorax, epigastric pain and nausea for 4 weeks. The patient's blood pressure was $150 / 90 \mathrm{~mm} \mathrm{Hg}$ and ejection-fraction on echocardiography was $30-35 \%$. An electrocardiogram showed a regular rhythm, with a widened ORS complex in all leads. There were notched $\mathrm{R}$ waves in V5, V6, aVL, II, III and aVF (figure 1). The small initial $\mathrm{R}$ waves in $\mathrm{V} 1$ and $\mathrm{V} 2$ were followed by deep $S$ waves and wide $S$ waves in left precordial leads (V5 and V6). The electrocardiogram showed characteristics of $L B B B$ and RBBB simultaneously and a wide ORS complex; thus, we suspected an intraventricular conduction defect (IVCD). The ECG appearance of the IVCD was difficult to characterise, because IVCD is often the end result of a number of different pathophysiological processes rather than a discrete defect in the conduction system (as usually occurs with RBBB or LBBB).

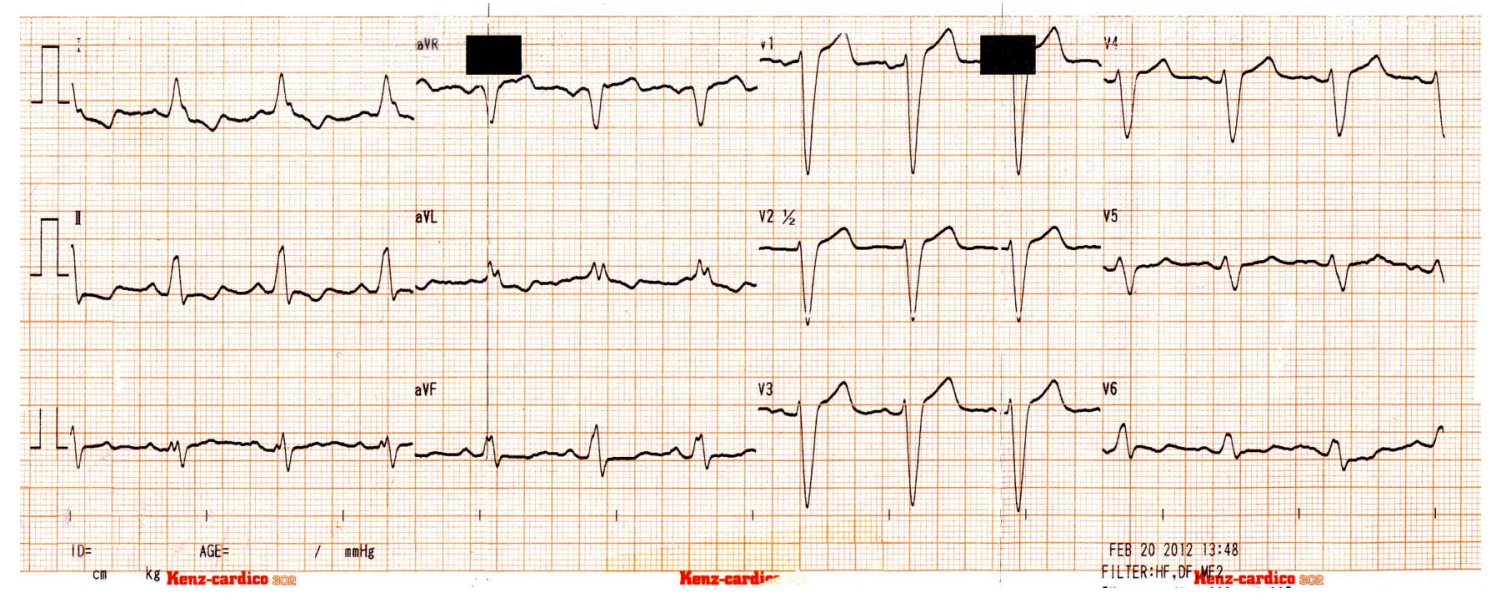

Figure 1 The EKG of the patient.

Copyright 2012 BMJ Publishing Group. All rights reserved. For permission to reuse any of this content visit http://group.bmj.com/group/rights-licensing/permissions.

BMJ Case Report Fellows may re-use this article for personal use and teaching without any further permission.

Please cite this article as follows (you will need to access the article online to obtain the date of publication).

Rashidbeygi M, Soleimannejad M. Intraventricular conduction defects. BMJ Case Reports 2012;10.1136/bcr-2012-007184, Published XXX

Become a Fellow of BMJ Case Reports today and you can:

- Submit as many cases as you like

- Enjoy fast sympathetic peer review and rapid publication of accepted articles

- Access all the published articles

- Re-use any of the published material for personal use and teaching without further permission

For information on Institutional Fellowships contact consortiasales@bmjgroup.com

Visit casereports.bmj.com for more articles like this and to become a Fellow 